\section{Ultimate Vacuum Attainable by a Diffusion Pump}

THE following experiments were recently performed to see the nature of pumping action inside a diffusion pump and to throw some light on the controversial question of the ultimate vacuum attainable by a diffusion pump.

While Gaede ${ }^{1}$ and Langmuir ${ }^{2}$ held that there is theoretically no limit to the vacuum produced by a diffusion pump, Hickman ${ }^{3,4}$ reported that the limit of pumping is set at the vapour pressure of the pump fluid at room temperatures, and he devised the 'selffractionating' oil-diffusion pump which is capable of producing higher vacuum. Newman ${ }^{5}$ believed that the pumping action would cease when the partial pressure of air, contained in the jet vapour as contamination, equals the pressure in the vessel.

Table 1 shows the pressure gradient down the barrel of an orthodox oil-diffusion pump with single umbrella-type jet, all brass and 4-in. in diameter. Tappings of nozzles were taken from seven different positions relative to the vapour jet, and could be connected to vacuum gauges. The pump was charged with Apiezon oil $B$, and had been in use for a few weeks.

A rubberless McLeod gauge was used for reading the pressure and also for calibrating a Pirani gauge. The Pirani gauge was calibrated across a liquid oxygen trap, so that without the trap the Pirani reads the total pressure (partials of air and vapour), as contrasted with a McLeod gauge which reads air pressure only.

Table 2 shows the vacuum (partial and total) attained by a three-stage mercury diffusion pump without a cold trap.

It is brought out clearly by the experiments that a diffusion pump can reduce the partial pressure of air far below the vapour pressure of the fluid, and so long as the pump is running, the vessel is not filled with the fluid vapour up to its saturation value for the room temperature. The partial pressure of air contamination of the jet will, similarly, not manifest itself fully in the vessel.

The successful functioning of a diffusion pump is apparently vitally dependent on the streamline issue of the jet vapour, and the small differences of vapour pressure of the fluid are not likely to affect the vacuum to any great extent. A perfect streamline flow of the jet vapour directed away from the diffusion aperture (neck) would cause only the diffusing out of the air (or vapour, etc.) from the vessel into the jet stream, where the molecules would

TABLE 1. DISTRIBUTION OF PRESSURE IN $\mu\left(10^{-8}\right.$ MM. HG) INSIDE A SINGLE-STAGE OIL-DIFFUSION PUMP (WITHOTT A TRAP).

\begin{tabular}{|c|c|c|c|c|}
\hline $\begin{array}{c}\text { Position of } \\
\text { tappings relative } \\
\text { to vapour jet } \\
1\end{array}$ & $\begin{array}{l}\text { Pressure n } \\
\text { McLeod } \\
\text { gauge } \\
\text { (partial } \\
\text { press. of } \\
\text { air) } \\
2\end{array}$ & $\begin{array}{l}\text { sured by } \\
\text { Pirani } \\
\text { gauge } \\
\text { (total } \\
\text { press.) } \\
\quad 3\end{array}$ & $\begin{array}{c}\text { Partial } \\
\text { press. of } \\
\text { oil vap. } \\
=\text { diff. of } \\
\text { cols. } 2 \& 3 \\
4\end{array}$ & $\begin{array}{l}\text { Ratio of } \\
\text { vap. press. } \\
\text { to air press. } \\
=\frac{\text { col. } 4}{\text { col. } \overline{2}}\end{array}$ \\
\hline $\begin{array}{c}\text { 1. } 7.0 \text { in. } \\
\text { above jet } \\
\text { 2. } 3.0 \text { in. } \\
\text { above jet } \\
\text { 3. } 1.5 \text { in. } \\
\text { above jet } \\
\text { 4. At the jet } \\
\text { 5. } 1.5 \text { in. } \\
\text { below jet } \\
\text { 6. } 3.0 \text { in. } \\
\text { below jet } \\
\text { 7. } 6.5 \text { in. be- } \\
\text { low jet (at } \\
\text { backing) }\end{array}$ & $\begin{array}{l}0.05 \\
0.02 \\
0.03 \\
4.0 \\
2 \cdot 5 \\
2 \cdot 0 \\
2.0\end{array}$ & $\begin{array}{l}0 \cdot 40 \\
0 \cdot 26 \\
0 \cdot 23 \\
6 \cdot 0 \\
8 \cdot 0 \\
5 \cdot 0 \\
4 \cdot 0\end{array}$ & $\begin{array}{l}0 \cdot 35 \\
0 \cdot 24 \\
0 \cdot 20 \\
2 \cdot 0 \\
5 \cdot 5 \\
3 \cdot 0 \\
2 \cdot 0\end{array}$ & $\begin{array}{c}7 \\
12 \\
6 \cdot 6 \\
0 \cdot 5 \\
2 \cdot 2 \\
1 \cdot 5 \\
1 \cdot 0\end{array}$ \\
\hline
\end{tabular}

TABLE 2. VACUUM PRODUCED BY A THREE-STAGE MERCURY-DIFFUSION PUMP. PRESSURE IN $\mu$ OR $10^{-3}$ MM. HG. (WITHOUT A TRAP).

\begin{tabular}{|c|c|c|c|c|}
\hline \multicolumn{2}{|c|}{ Measured by } & \multirow{3}{*}{$\begin{array}{c}\text { Partial } \\
\text { press. of } \\
\text { Hg (diff. of } \\
1 \text { and 2) } \\
3\end{array}$} & \multirow{3}{*}{$\begin{array}{c}\text { Vapour } \\
\text { press. of } \\
\text { Hg at room } \\
\text { temp. } 26^{\circ} \mathrm{C} . \\
4\end{array}$} & \multirow{3}{*}{ 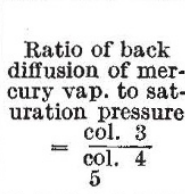 } \\
\hline $\begin{array}{l}\text { McLeod } \\
\text { gauge }\end{array}$ & $\begin{array}{l}\text { Pirani } \\
\text { gauge }\end{array}$ & & & \\
\hline 1 & 2 & & & \\
\hline 0.02 & 0.50 & 0.48 & $2 \cdot 0$ & 0.24 \\
\hline
\end{tabular}

be caught by the forward stream of vapour and knocked on towards the backing pump, and would lead theoretically to perfect vacuum with time.

The practical vacuum, however, would depend upon the degree of back-streaming at the jet for several reasons, chiefly, the imperfection of the jet design, and the turbulence and pressure condition below the jet. The back-diffusion consists of vapour (easy to freeze out) as well as air. The latter (air) comes from the contaminated fluid from the boiler where the fluid returns through the air-laden column at the lower ('compression') part of the diffusion pump barrel. The turbulent condition set up by the abrupt rise of pressure below the single jet is also responsible for the back-escape.

The process of 'self-fractionation', originated by Hickman, not only helps in grading out the degenerated fractions of the oil but also helps very much in freeing oils of the inner compartments from air contamination. The inclusion of a number of jets in the fractionating pump also helps in getting more perfect streamline flow of vapour at the upper jets. This picture accords well with the success of a fractionating oil diffusion pump without laying too much stress on the vapour pressure of pump fluid, as demanded by the diffusion theory and the present experimental evidence.

Work is in progress and the details will be published elsewhere.

Our thanks are due to Prof. M. N. Saha for his keen interest in the work. Our thanks are also due to Mr. J. R. Basu Mallik, for designing the tappings and getting the oil diffusion pump constructed for the purpose. We also acknowledge our thanks to the authorities of the Board of Scientific and Industrial Research for kindly permitting the work to be published.

Kamalesh Ray.

Nanda Dulal Sengupta.

Palit Laboratory of Physics,

University College of Science,

92, Upper Circular Road,

Calcutta. March 14.

${ }^{1}$ Gaede, W., Ann. Phys., 46, 357 (1915).

Langmuir, I., Phys. Rev., 8, 48 (1916).

Hickman, K. C. D., J. Frank. Inst., 221, 215 (1936).

- Hickman, K. C. D., J. App. Phys., 11, 303 (1940). 'Newman, F. H., "Production and Measurement of High Vacuum",
52 .

\section{Codecarboxylase Function of 'Pyridoxal Phosphate'}

SIx specific amino-acid decarboxylases have now been obtained in a cell-free state from various bacteria ${ }^{1,2,3,4}$. Of these, the enzymes decarboxylating $l(+)$-lysine, $l(-)$-tyrosine, $l(+)$-arginine and $l(+)$-ornithine have been resolved into apoenzyme moieties activated by the presence of a common codecarboxylase of which a concentrate has been prepared from yeast ${ }^{5}$. The remaining enzymes, 